\title{
DEVELOPMENT AND USE OF EMISSIONS INVENTORIES FOR CONSTRUCTION VEHICLES
}

\author{
Phil Lewis, PE \\ $\mathrm{PhD}$ Candidate \\ Department of Civil, Construction and Environmental Engineering \\ North Carolina State University \\ Campus Box 7908, Raleigh, NC 27695-7908 \\ (O) (919) 515-2331, (F) (919) 515-7908 \\ phillewis@bellsouth.net \\ H. Christopher Frey, Ph.D. \\ Professor, Department of Civil, Construction and Environmental Engineering \\ North Carolina State University \\ Campus Box 7908, Raleigh, NC 27695-7908 \\ (O) (919) 515-1155, (F) (919) 515-7908 \\ frey@ncsu.edu \\ William Rasdorf, Ph.D., PE \\ Professor, Department of Civil, Construction and Environmental Engineering \\ North Carolina State University \\ Campus Box 7908, Raleigh, NC 27695-7908 \\ (O) (919) 515-7637, (F) (919) 515-7908 \\ rasdorf@ncsu.edu
}

Text words 5,975 plus 1,500 words for 6 Tables/Figures $=7,475$ Words 


\begin{abstract}
There is a lack of real-world data from which to estimate actual emissions from construction vehicles and from which to develop effective decisions aimed at reducing emissions. A methodology is developed here for inventorying construction fleet emissions based on representative real-world measurements of construction vehicles using a portable emissions measurement system (PEMS). The PEMS enables measurements of actual duty cycles and their corresponding fuel use and emissions. The methodology is demonstrated via application to a fleet of publicly-owned construction vehicles used primarily for highway maintenance. Selected backhoes, front-end loaders, and motor graders, representing various model years and engine emissions standards, were measured in-use with PEMS. Tests were performed for B20 biodiesel and petroleum diesel. Emission factors from the PEMS data, combined with annual fuel use owner records for over 1,000 vehicles, were used to estimate annual inventories of tailpipe emissions of nitrogen oxides $\left(\mathrm{NO}_{\mathrm{x}}\right)$, particulate matter $(\mathrm{PM})$, hydrocarbons $(\mathrm{HC})$, and carbon monoxide (CO). The emissions inventory was stratified by pollutant, vehicle type, fuel type, and engine tier. The inventory was used to assess fleet management strategies aimed at reducing emissions. Case study results illustrate that total fleet emissions would be reduced by: $3 \%$ to $24 \%$ when using B20 exclusively instead of petroleum diesel exclusively; $11 \%$ to $50 \%$ when replacing all Tier 0 and Tier 1 engines with Tier 2 engines; and 31\% to $72 \%$ when using B20 exclusively in the highest engine tier available. Recommendations are made regarding the development and practical applications of inventories for construction fleet management.
\end{abstract}




\section{INTRODUCTION}

An emissions inventory lists the amounts of air pollutants emitted for a specific area, time period, and set of sources and are often used to support emissions standards and compliance activities (1). They can provide insight regarding the distribution of emissions among source categories, such as power plants, highway vehicles, and nonroad vehicles. Nonroad vehicles include boats, planes, trains, construction equipment, and others (2).

Diesel engines of nonroad construction vehicles emit significant amounts of nitrogen oxides $\left(\mathrm{NO}_{\mathrm{x}}\right)$ and particulate matter $(\mathrm{PM})$, as well as carbon monoxide $(\mathrm{CO})$ and hydrocarbons $(\mathrm{HC})$. These pollutants pose adverse effects on human health and the environment.

The objective of this paper is to present a new methodology for developing an emissions inventory for construction vehicles based on real-world data. The methodology is illustrated for a case study of selected construction vehicles. As demonstrated here, emissions inventories may be used to compare vehicle types, fuel types, and engine tiers, and to evaluate emissions reduction strategies.

\section{CONSTRUCTION VEHICLES}

This section addresses issues that are associated with selected construction vehicles that are used for highway maintenance as well as other tasks, including the types of vehicles that are used, the air pollutant emissions from them, the tier classifications of the engines that power these vehicles, and the types of fuel that they use.

\section{Vehicle Types}

Three construction vehicles that are frequently used include backhoes, front-end loaders, and motor graders.

The backhoe combines the capabilities of a small front-end loader and a small excavator. The backhoe is equipped with a loader bucket on the front and an excavator boom and bucket on the rear. It is a wheel-mounted tractor and has exceptional maneuverability. The ability to perform a wide range of activities (such as excavate earth, move bulk material, and load trucks) makes the backhoe a productive member of highway, construction, and maintenance fleets.

Front-end loaders are front-end tractor shovels and thus similar to bulldozers. The tractor may be wheel-mounted on rubber tires or crawler-mounted on steel tracks. Rubber tire loaders are more commonly used for highway maintenance activities. Loaders are used for digging, loading, rough grading, and limited hauling.

The motor grader is a wheel-mounted tractor with an undercarriage blade used for scraping and spreading material. Common activities performed by motor graders include general road maintenance, road construction, ditch building and cleaning, and snow removal.

\section{Air Pollutants}

According to results from the EPA NONROAD model (3), backhoes emit more CO and $\mathrm{PM}_{10}$ than any other construction vehicle. Front-end loaders are the number one contributor of $\mathrm{NO}_{\mathrm{x}}$ and motor graders rank $12^{\text {th }}$ and $13^{\text {th }}$ for emissions of $\mathrm{NO}_{\mathrm{x}}$ and $\mathrm{PM}_{10}$, respectively.

$\mathrm{NO}_{\mathrm{x}}, \mathrm{CO}$, and PM are subject to the National Ambient Air Quality Standards (NAAQS) (4). Although $\mathrm{HC}$ is not a criteria pollutant, it is a precursor, as is $\mathrm{NO}_{2}$, to the formation of ozone, 
which is a criteria pollutant. Ozone causes health problems, plant damage, and material degradation. PM contributes to smog and haze and can cause severe breathing difficulty. CO can hinder basic human faculties, such as impaired vision, and at extremely high levels can cause death, although not likely at ambient conditions (5).

\section{Engine Tiers}

Regulatory and incentive programs for reducing emissions from nonroad diesel construction vehicles are discussed in detail by Lewis et al (6). EPA (7) provides a summary of emissions standards for nonroad diesel vehicles.

In 1994, the United States Environmental Protection Agency (EPA) adopted emission standards, known as engine tiers, for all new nonroad diesel engines. Diesel engines manufactured after a specified date must meet the performance levels specified in that standard. The EPA engine tier classifications include successive Tier 1, Tier 2, Tier 3, Tier 4 Transitional, and Tier 4 Final, which are effective in reducing emissions in a phased sequence from 1996 to 2013 (7).

Prior to the implementation of Tier 1 standards, there were no EPA required regulations for the emissions of $\mathrm{NO}_{\mathrm{x}}, \mathrm{PM}, \mathrm{CO}$, and $\mathrm{HC}$. However, there are many construction vehicles still in use today which have pre-Tier 1 engines. Such engines are referred to as Tier 0 engines.

Tier 1 standards represent the first and least stringent level of emissions regulations for nonroad diesel engines. Tier 1 standards were phased in between 1996 and 1998 depending on the engine horsepower rating.

The second level of EPA emissions regulations are known as Tier 2 standards. These regulations were more stringent than Tier 1 and they were phased in between 2001 and 2004 depending on the engine horsepower rating.

The third level of EPA emissions regulations are Tier 3 standards and are more stringent than Tier 2 standards. Tier 3 standards were phased in between 2006 and 2008 depending on the engine horsepower rating.

The most stringent EPA emissions regulations will be implemented in two phases: Tier 4 Transitional standards and Tier 4 Final standards. Depending on the engine horsepower rating, Tier 4 Transitional regulations will be phased in beginning in 2008 and Tier 4 Final regulations will be phased in beginning in 2013 .

\section{Fuel Types}

Most nonroad construction vehicles operate on diesel fuel. Under the Energy Policy Act of 1992, the use of alternative fuels, such as biodiesel, is encouraged to reduce the nation's dependence on imported oil (8).

In 2004, EPA's Clean Air Nonroad Diesel Rule required that sulfur levels in highway diesel fuel be reduced by approximately $99 \%$ from 3000 parts per million to 15 ppm (known as ultralow sulfur diesel fuel) by 2006 (9). In 2007, low sulfur diesel fuel with a sulfur content of 500 ppm or less was required for nonroad diesel engines. Ultra-low sulfur diesel fuel will be required for nonroad diesel engines in 2010 (10). The reduced sulfur content is necessary to avoid poisoning catalytic control systems that are anticipated to be needed under stringent emissions standards.

Biodiesel is an alternative and renewable fuel that is made from agricultural products such as vegetable oils. Although most biodiesel is made from soybean oil, it can also be made from 
canola oil, sunflower oil, recycled cooking oils, and animal fats. Biodiesel is registered with the EPA and is a legal fuel at any blend level for use in highway and nonroad vehicles (11).

Biodiesel can be blended with petroleum diesel for use in vehicles. Biodiesel blend stock is known as B100 (100\% biodiesel). B20 (20\% B100 and $80 \%$ petroleum diesel) is a common blend level used for public transportation fleets and other programs (12).

Although petroleum diesel and biodiesel have many similar characteristics, there are potential key differences, some of which depend on fuel quality. For instance, a one percent blend of biodiesel can provide up to $30 \%$ improved fuel lubricity over petroleum diesel alone. Cold weather can cloud and gel both types of fuel but B20 can experience these problems at 3-to-5 $\mathrm{F}^{\mathrm{o}}$ warmer temperatures than petroleum diesel. The high oxygenate content of biodiesel may enhance oxidation degradation into gummy residues and varnish that can cause fuel injector deposits or clog fuel filters (12). However, many potential problems with biodiesel blends can be avoided by adhering to ASTM D6751-08 "Specification for Diesel Fuel Blend Stock (B100) for Middle Distillate Fuels" which is often specified by fuel buyers in order to assure quality of B100 that is blended with conventional diesel fuels (20). B20 requires average increases of 2.2\% in volume and $3.4 \%$ in mass to provide the same amount of chemical energy as petroleum diesel (13).

Perhaps the best advantage of biodiesel blends is that emissions of $\mathrm{PM}, \mathrm{CO}$, and $\mathrm{HC}$ are reduced proportionally to the ratio of biodiesel to petroleum diesel in the blend. Compared to petroleum diesel alone, a B20 blend reduces average emissions by approximately $20 \%$ for $\mathrm{HC}$ and approximately $12 \%$ for both PM and CO. A B100 blend reduces average emissions by approximately $67 \%$ for $\mathrm{HC}$ and approximately $48 \%$ for both PM and CO. The results for $\mathrm{NO}_{\mathrm{x}}$ emissions are not as certain. Some studies have indicated slight increases in $\mathrm{NO}_{\mathrm{x}}$ emissions when biodiesel blends are used compared to petroleum diesel, whereas other studies have indicated slight decreases in $\mathrm{NO}_{\mathrm{x}}$ emissions $(13-15)$.

For the case study fleet, the vehicles were fueled with either petroleum diesel or B20 biodiesel. For B20 fuel use, the fleet owner used the current ASTM standards for biodiesel blend stock quality control. Furthermore, the fleet owner required measured verification of the fuel properties.

\section{METHODOLOGY}

There are three primary components of the emissions inventory: (1) average emission rates; (2) average annual fuel use; and (3) estimated average annual emissions. The average emission rates are expressed in terms of grams of pollutant emitted per gallon of fuel used (g/gallon). The average annual fuel use is in terms of gallons of fuel consumed in one year (gallon/yr). The estimated average annual emissions (tons/yr) were obtained by multiplying the average emission rate by the average annual fuel use. This information was then used to evaluate three emissions reduction strategies: (1) substitution of B20 for petroleum diesel, (2) replacement of older vehicles with newer vehicles, and (3) using B20 exclusively in the newest vehicles available.

This methodology is illustrated by a case study for a public road maintenance fleet. In 2007, North Carolina State University (NCSU) completed a research project for the North Carolina Department of Transportation (NCDOT) in which emissions from five backhoes, four front-end loaders (rubber tire loaders), and six motor graders were measured (14 - 17). The primary objectives of this project were to measure real-world, in-use duty cycles and emissions of these highway maintenance vehicles, develop recommended duty cycles and emissions estimates to be 
used for operational evaluation, and develop a case study to represent how real-world emissions data can be used to develop an emissions inventory for NCDOT vehicles. These vehicles are primarily used for highway maintenance activities. However, many of the observed duty cycles are common to other vehicle applications, such as road construction.

The data collected from these vehicles was used to estimate average annual emissions for all of these types of vehicles in the NCDOT fleet. This inventory is used to gain insight into the real world implications of emissions from these vehicles based on increasingly stringent engine tier regulations and substitution of soy-based B20 for petroleum diesel. These insights are useful when evaluating the benefits of emissions reduction strategies, such as replacing older vehicles with newer ones or using an alternative fuel that may be cleaner burning but more expensive.

The emissions inventory is categorized by pollutant type, vehicle type, fuel type, and engine tier. The NCDOT statewide fleet of backhoes, front-end loaders, and motor graders will be collectively referred to as "the case study fleet" for the remainder of this paper.

\section{Real-World Emissions Measurements}

The real-world activity, fuel use, and emission rates of the tested vehicles were measured using a Portable Emissions Measurement System (PEMS). The PEMS used here is the Montana System manufactured by Clean Air Technologies International, Inc. The PEMS uses non-dispersive infrared (NDIR) detection to measure $\mathrm{CO}_{2}, \mathrm{CO}$, and $\mathrm{HC}$, and uses electrochemical cells to measure $\mathrm{NO}$ and $\mathrm{O}_{2}$. PM is measured using a light scattering laser photometer detection method. A detailed assessment of the precision and accuracy of the PEMS is reported by Battelle (18).

The PEMS produces accurate data for $\mathrm{NO}, \mathrm{CO}$, and $\mathrm{CO}_{2}$. The $\mathrm{HC}$ data tend to be based low because NDIR responds more accurately to straight chain HC than to aromatic compounds (19). Thus, the reported emission factors may be low by a factor of two.

The PM detection method is analogous to opacity. The PM measurements are useful for relative comparisons of PM emission rates for different fuels or engine tiers, but not for characterization of the absolute magnitude of such emissions. Previous comparisons of the opacity-based measurements to other PM data imply that absolute values inferred from the opacity-based measurements could be low by an order of magnitude.

Emission rates were measured using the PEMS for each pollutant type, each vehicle type, each fuel type, and engine tier. The measurements occurred during real-world duty cycles. The data that were collected in the field underwent data screening and quality assurance procedures to determine whether any errors or problems existed in the data, to correct such errors or problems when possible, and to remove invalid data if the errors or problems could not be corrected. The goal of data screening and quality assurance was to produce a database that contained valid data. Only those data that could be corrected were excluded from the final database that was used for analysis. On average, approximately seven percent of the raw secondby-second data were excluded from the final processed data that were used for analysis $(14,15)$.

\section{Average Emission Rates}

Emission rates are the ratios of emissions to vehicle activity. Vehicle activity can be quantified with respect to time or fuel use. Therefore, emission rates may be determined in units of mass per time or mass per gallon of fuel used (15). 
Emission rate units of mass per time are useful when the total amount of time that a vehicle is operating can be accurately estimated. Alternatively, an emission rate in units of mass per gallon of fuel used is practical when the total fuel use for a vehicle or a fleet of similar vehicles can be estimated or measured (14). The average emission rates used in the emissions inventory were based on fuel use because NCDOT was able to provide two years of fuel use data from their records, including both $\mathrm{B} 20$ and petroleum diesel.

NCDOT also provided the vehicle model year and engine horsepower rating of each vehicle in their fleet of over 1,000 backhoes, front-end loaders, and motor graders. Therefore, it was possible to classify the vehicles based on the EPA engine tier classification. Each vehicle in the case study fleet was categorized from Tier 0 to Tier 2 . There were some Tier 3 motor graders placed into service during 2007 but the average annual emissions could not be determined because there was no fuel use history for these vehicles. However, a Tier 3 motor grader was tested and an average emission rate was measured.

The average emission rates reported here were averaged over multiple duty cycles. Duty cycles are the sum of the components that a specific vehicle performs on a job site to complete a task. Each vehicle is capable of performing different duty cycles and each duty cycle has its own emission rate. For example, the backhoes were measured during duty cycles for loading trucks, mass excavation, and material handling. The fuel-based emission factors were found to be less sensitive to variability among duty cycles than time-based emission factors $(14,15)$. The overall average emission rates for each vehicle represent the average of the emission rates that were observed for each duty cycle for each vehicle during the field data collection.

\section{Average Annual Fuel Use}

The fuel use data provided by the fleet owner included the number of gallons of petroleum diesel and B20 that was consumed by each vehicle of the case study fleet during the years of 2005 and 2006. Thus, it was possible to stratify the fuel usage according to engine tier for each type of vehicle and each type of fuel.

The fuel use was averaged for the years of 2005 and 2006 to determine a typical average annual fuel use in units of gallons per year for both petroleum diesel and B20. This average annual fuel use was multiplied by the average emission rate to determine the estimated average annual emissions.

\section{Estimated Average Annual Emissions}

To calculate the estimated average annual emissions, the appropriate average emission rate was multiplied by the average annual fuel use. The results were computed in terms of grams per year for each pollutant but were converted to and reported as tons per year. The average annual emissions were estimated for each pollutant based on vehicle type, fuel type, and engine tier.

\section{Emissions Reduction Strategies}

Three emission reduction strategies considered here are: (1) increased use of B20 in lieu of petroleum diesel; (2) replacement of older vehicles with newer ones; and (3) use of B20 exclusively in the newest vehicles available. Therefore, comparisons were made between the existing vehicle usage and a set of competing scenarios. 
For B20 fuel use, the average annual emissions for each pollutant and each type of vehicle were estimated based on the following scenarios:

- Current fuel mix including both petroleum diesel and B20

- Petroleum diesel use only and no B20 use

- B20 use only and no petroleum diesel use

Comparisons among these scenarios enable assessment of the emissions benefits of the current fuel mix versus petroleum diesel, as well as regarding more widespread use of B20 either versus the current situation or a petroleum diesel baseline.

For comparison of newer vehicles versus older ones, the average annual emissions for each pollutant and each type of vehicle were estimated based on the following scenarios:

- Current distribution of engine tier classifications of the case study fleet

- Replace all vehicles with Tier 0 and Tier 1 engines with vehicles that have Tier 2 engines

- Replace all Tier 0, Tier 1, and Tier 2 motor graders with Tier 3 motor graders

These scenarios enable assessment of the emissions benefits of replacing older vehicles with newer ones. In order to assess the possible emissions reduction benefits from a combination of widespread use of B20 and replacement of older vehicles with newer ones, average annual emissions are estimated based on using B20 in the lowest emitting engine tier available for each vehicle type.

\section{RESULTS}

This section reports on the results of the average emission rates, average annual fuel use, and estimated average annual emissions that were determined in the emissions inventory. Results of the evaluation of the emissions reduction strategies are discussed.

\section{Average Emission Rates}

Table 1 summarizes the measured average emission rates that were used to determine the estimated average annual emissions for the case study fleet. This database of 15 vehicles for which real-world emissions were measured and compared for both fuels is the largest available database of its kind at this time. Due to their higher average engine load associated with realworld duty cycles, front-end loaders have the highest average emission rate of NO for each type of fuel. Backhoes have the highest average emission rates for PM and CO for each type of fuel. Motor graders have the highest average emission rates of $\mathrm{HC}$ for each type of fuel.

For each type of vehicle, Table 1 shows the reduction in the overall average emission rates for each pollutant when using B20 versus petroleum diesel. For each vehicle type, the PM emission rates are reduced $14 \%$ to $20 \%, \mathrm{CO}$ is reduced $17 \%$ to $24 \%$, and $\mathrm{HC}$ is reduced $20 \%$ to $40 \%$. The average emission rates of B20 for $\mathrm{NO}$ are between zero percent and three percent less than the average emission rates of petroleum diesel for $\mathrm{NO}$ for each type of vehicle. The percentage reductions in the emission rates of $\mathrm{PM}, \mathrm{CO}$, and $\mathrm{HC}$ are qualitatively consistent with other data. The observed small decreases in NO emission rates for the backhoes and front-end loaders are not significant and are interpreted to be consistent with no net change.

Table 1 indicates that for each vehicle type and each fuel type, the average emission rate decreases as the engine tier increases. For example, Tier 2 backhoes using petroleum diesel emit an average of $5.7 \%$ less NO than Tier 0 backhoes, as well as $41 \%$ less PM, 85\% less CO, and 


\section{TABLE 1 Measured Average Emission Rates of B20 Biodiesel versus Petroleum Diesel for NCDOT Backhoes, Front-End Loaders, and Motor Graders}

$32 \%$ less HC. Tier 3 motor graders using B20 emit an average of $47 \%$ less NO than Tier 0 motor graders, as well as $42 \%$ less PM, 79\% less CO, and 66\% less HC. These results suggest that the EPA engine tier regulations are having the desired effect of reducing real-world air pollutant emissions from nonroad diesel engines.

\section{Average Annual Fuel Use}

Table 2 summarizes the estimated average annual fuel use that was used to determine the estimated average annual emissions for the case study fleet. The total gallons of B20 and petroleum diesel that were used by each vehicle type and each engine tier are presented. The total number of vehicles is categorized by engine tier for each vehicle type.

The case study fleet consists of 1,025 vehicles that annually used approximately 181,000 gallons of B20 and over 975,000 gallons of petroleum diesel. B20 comprised approximately $16 \%$ of total annual fuel consumption. Some of the vehicles in the case study fleet used only B20, some used only petroleum diesel, and some used both B20 and petroleum diesel throughout the year.

Approximately $40 \%$ of these vehicles utilized a Tier 0 engine, which represents no regulation. Tier 1 engines account for $44 \%$ of the case study fleet. Tier 0 engines consumed approximately $28 \%$ of total annual B20 and approximately $24 \%$ of total annual petroleum diesel used by the case study fleet. Tier 2 engines consumed approximately 16,500 gallons of B20 and approximately 217,400 gallons of petroleum diesel.

\section{TABLE 2 Estimated Average Annual Fuel Use for Backhoes, Front-End Loaders, and Motor Graders in the Case Study Fleet}

\section{Average Annual Emissions}

Table 3 summarizes and compares the estimated average annual emissions from the case study fleet for each pollutant based on actual B20 and petroleum diesel fuel use. Based on vehicle type, motor graders annually emit the most NO, Opacity, CO, and HC from the case study fleet. This is due to their large population and total fuel use in comparison to backhoes and front-end loaders. Based on fuel type, approximately $84 \%$ of the fuel used by the case study fleet is petroleum diesel and approximately $84 \%$ of annual average emissions for each pollutant are attributable to petroleum diesel. Based on engine tier, approximately $82 \%$ of the case study fleet has Tier 0 or Tier 1 engines and they emit between $82 \%$ and $89 \%$ of each pollutant.

\section{Emissions Reduction Strategies}

Table 4 compares the results of the fuel use scenarios for the case study fleet. The combined usage of petroleum diesel and B20 that was used at the time is considered to be the base case and is referred to as the "Current Mix." The absolute and relative differences between the base case and both the petroleum diesel only and B20 only scenarios are computed, as well as the absolute and relative differences between B20 only and petroleum diesel only. The difference in heating 
values for each fuel was accounted for when estimating the average annual fuel use for each scenario.

The use of the current mix instead of petroleum diesel only has led to estimated decreases in emissions of each pollutant for each type of vehicle. NO emissions have decreased $0.5 \%$ to $0.9 \%$ for each type of vehicle. PM, HC, and CO emissions have decreased $2.6 \%$ to $6.7 \%$ for each type of vehicle.

Using B20 only instead of the current mix in the case study fleet would result in additional decreases in emissions of each pollutant for each type of vehicle. $\mathrm{NO}_{\mathrm{x}}$ emissions would decrease $2.0 \%$ to $4.7 \%$ for each type of vehicle compared to the current mix. PM, HC, and CO emissions would decrease $11 \%$ to $37 \%$ for each type of vehicle.

\section{TABLE 3 Estimated Average Annual Emissions for Backhoes, Front-End Loaders, and Motor Graders in the Case Study Fleet}

A possible future policy of exclusive use of B20 is evaluated by comparing B20 only fuel use to petroleum diesel only fuel use. In this case, $\mathrm{NO}$ emissions would decrease approximately $2.4 \%$ to $5.7 \%$ for each type of vehicle. PM, HC, and CO emissions would decrease $15 \%$ to $42 \%$. Thus, such a strategy would result in significant emissions decreases of each pollutant from each type of vehicle.

Table 5 compares the engine tier scenarios for the case study fleet. The distribution of the engine tiers that were being used at the time are considered to be the base case and are referred to as the "Current Engine Tiers." The emissions for the current engine tiers were calculated using the current fuel mix of B20 and petroleum diesel. The engine tier scenarios were based on the presumption of replacing all lower tier engines with the highest tier currently available.

The first comparison shown in Table 5 includes the percentage change between the base case and hypothetical replacement of all Tier 0 and Tier 1 engines with Tier 2 engines for each type of vehicle. The results for the second comparison is the percentage change between the base case and hypothetical replacement of all Tier 0, Tier 1, and Tier 2 motor graders with Tier 3 motor graders. At the time of this comparison, NCDOT did not have any Tier 3 backhoes or Tier 3 front-end loaders in service, thus it was not possible to estimate the average annual emissions for those vehicles.

Replacing Tier 0 and Tier 1 engines with Tier 2 engines would reduce NO emissions by $4.3 \%$ to $16 \%$ depending on the type of vehicle. Opacity, $\mathrm{HC}$, and $\mathrm{CO}$ emissions would be reduced by $14 \%$ to $78 \%$ depending on the pollutant and the type of vehicle. Thus, an emissions reduction strategy that replaces vehicles that have Tier 0 and Tier 1 engines with vehicles that have Tier 2 engines will have a significant impact on total emissions reductions.

\section{TABLE 4 Estimated Average Annual Emissions Comparisons Based on Fuel Type for Backhoes, Front-End Loaders, and Motor Graders in the Case Study Fleet ${ }^{1}$}

Reductions for each pollutant are observed by replacing motor graders with Tier 0 , Tier 1 , and Tier 2 engines with those that have Tier 3 engines. $\mathrm{NO}_{\mathrm{x}}$ emissions would be reduced by $39 \%$ and $\mathrm{PM}, \mathrm{HC}$, and $\mathrm{CO}$ would be reduced by approximately $31 \%, 60 \%$, and $52 \%$, respectively. These reductions are 30 percent to 3.3 times greater than the reductions from replacing Tier 0 and Tier 1 motor grader engines with Tier 2 motor grader engines. Thus, an emissions strategy that employs only the highest available engine tiers will reduce emissions significantly. 
To assess the maximum potential benefit of using alternative fuel and the newest vehicles, Table 6 provides a comparison of a hypothetical policy to use B20 exclusively in the highest available engine tier for each vehicle type. The base case here is the distribution of the current fuel mix and the current engine tier classifications, referred to as "Current Fuel Mix and Tiers." For backhoes and front-end loaders, the average annual emissions were estimated using the B20 average emission rate for Tier 2 engines. For motor graders, average annual emissions were estimated using the B20 emission rate for a Tier 3 engine.

If B20 only is used in vehicles with the highest available engine tier, NO would be reduced by approximately $7.5 \%$ to $39 \%$ for each vehicle type. PM, HC, and CO emissions would be reduced by approximately $21 \%$ to $82 \%$ for each vehicle type. Thus, an emissions reduction strategy that uses only B20 in the highest engine tier available would lead to substantial reductions.

\section{TABLE 5 Estimated Average Annual Emissions Comparisons Based on Engine Tier Classifications for Backhoes, Front-End Loaders, and Motor Graders in the Case Study Fleet $^{1}$}

Tables 4, 5, and 6 indicate results for three emissions reduction strategies Although each strategy is effective in reducing emissions, the most effective strategy is using B20 only in the highest engine tier available for each vehicle.

\section{CONCLUSIONS \& RECOMMENDATIONS}

All types of construction vehicle fleets can benefit from emissions inventory evaluation, including grading contractors with large earthmoving machines, general contractors with a wide variety of construction vehicles and equipment, and equipment rental companies that have large quantities of vehicles and a wide variety of equipment. Managers for these types of fleets can use emissions inventories to evaluate their fleet's emissions and fuel use performance to minimize their contribution to air pollution.

The case study emissions inventory showed that the average emission rates for B20 are significantly lower than petroleum diesel for PM, CO, and $\mathrm{HC}$ and are similar for NO. Thus, fleet managers should consider using more B20 and less petroleum diesel in order to reduce emissions. In fact, fleet managers can evaluate using B20 exclusively to have a more significant impact on the reduction of these emissions. Other blends of biodiesel, such as B30 and B40, should be evaluated. The benefits of substantial emissions reductions should be compared with potential adverse yet perhaps manageable negative operational impacts from biodiesel, which may vary depending on the location and climate of a particular fleet.

\section{TABLE 6 Estimated Average Annual Emissions Based on Using B20 Only in the Highest Available Engine Tier for Backhoes, Front-End Loaders, and Motor Graders in the Case Study Fleet}

Likewise, the case study emissions inventory showed that average emission rates are lower for higher tier engines than lower tier engines. Therefore, fleet managers should evaluate and claim credit for the reduction in emissions when older, lower tier engines with high emission rates are replaced with newer, higher tier engines with lower emission rates. Although it is 
usually not feasible to replace an entire fleet of older vehicles at one time, this information can help agencies and fleet owners such as NCDOT to decide and provide justification regarding which vehicles should be replaced first.

Combining the benefits of both biodiesel and newer vehicles is a highly effective emissions reduction strategy. Using B20 in the highest available engine tier would provide greater reductions in emissions than a strategy that uses B20 only in a fleet with a mixed distribution of engine tiers or a strategy that replaces older vehicles with newer ones that use only petroleum diesel.

Some fleets are required to retrofit existing vehicles with emission control systems. However, the remaining service life of such vehicles is less than that of a new vehicle. Furthermore, the retrofitted emission rate may not be as low as that for a new vehicle. Thus, when allocating scarce capital procurement dollars, consideration should be given to the trade-off between retrofitting existing vehicles versus replacing older vehicles with newer ones.

Emissions inventories can be used for environmental modeling tasks. For example, each vehicle in the case study fleet is assigned to a particular geographic location according to county and municipality. Therefore, it is possible to use the emissions inventory information to model air quality in a particular area of the state and determine the impact of the fleet on human health and the environment. Counties that are in nonattainment status for EPA criteria air pollutants can be more closely assessed with regard to the local impact of vehicle fleets.

Although the vehicle emissions sample used here is relatively small, at 15 vehicles, it is the largest such database currently available to support comparisons of fuels and engine tiers based on real world measurements. These data can be augmented with additional measurements to increase sample size. The methodology demonstrated here is recommended for application to other fleets to support fleet and air quality management decision-making.

\section{ACKNOWLEDGEMENT}

This study was supported as research Project HWY-2006-08 by the U.S. Department of Transportation and the North Carolina Department of Transportation through the Institute for Transportation Research and Education, NC State University. The NCDOT Research and Development Branch, Equipment and Maintenance Unit, and NCDOT Divisions 4 and 5 maintenance yards have provided valuable assistance and cooperation. Shih-Hao Pang, $\mathrm{PhD}$ assisted with the calculations for the emissions inventory. 


\section{REFERENCES}

1. NARSTO. Improving Emission Inventories for Effective Air Quality Management Across North America, A NARSTO Assessment, NARSTO-05-001, Prepared by NARSTO, 2005. Available at: www.narsto.org/section.src?SID=8.

2. Cooper, C.D. and F.C. Alley. Air Pollution Control: A Design Approach. Waveland Press, Long Grove, Illinois, 2002.

3. EPA. User's Guide for the Final NONROAD2005 MODEL. EPA-420-R-05-013, U.S. Environmental Protection Agency, Ann Arbor, MI, 2005.

4. CFR. Title 40 - Protection of Environment, Part 50 - National Primary and Secondary Ambient Air Quality Standards, Code of Federal Regulations, Vol. 2, pp. 5 - 127, 2007. Available at www.access.gpo.gov/nara/cfr/waisidx 07/40cfr50 07.html.

5. EPA. Latest Findings on National Air Quality. EPA-454-R-07-007, U.S. Environmental Protection Agency, Research Triangle Park, NC, 2008.

6. Lewis, P., W. Rasdorf, H.C. Frey, K. Kim, and S.H. Pang. Air Pollutant Regulations and Comparison of Nonroad Diesel Engine Emissions Data Sources. Journal of Construction Engineering and Management, American Society of Civil Engineers, Submitted April 2008.

7. EPA. Exhaust and Crankcase Emission Factors for Nonroad Engine Modeling Compression-Ignition. EPA-420-P-04-009, NR-009c, U.S. Environmental Protection Agency, Ann Arbor, MI, 2004.

8. NREL. EPAct Fleet Information \& Regulations. DOE/GO-102005-2012, Prepared by the National Renewable Energy Laboratory, Golden, CO, 2005.

9. EPA. Clean Air Nonroad Diesel Rule Summary. EPA-420-F-04-029, U.S. Environmental Protection Agency, Ann Arbor, MI 2005.

10. EPA. National Clean Diesel Campaign Fact Sheet. EPA-420-F-05-012, U.S. Environmental Protection Agency, Ann Arbor, MI, 2005.

11. EPA. Alternative Fuels: Biodiesel. EPA-420-F-06-044, U.S. Environmental Protection Agency, Ann Arbor, MI, 2006.

12. AEM. New Diesel Fuels: They Are in Your Future for Nonroad Equipment. Association of Equipment Manufacturers, West Allis, WI, 2001.

13. EPA. A Comprehensive Analysis of Biodiesel Impacts on Exhaust Emissions. EPA-420-P02-001, U.S. Environmental Protection Agency, Ann Arbor, MI, 2002.

14. Frey, H.C., W. Rasdorf, K. Kim, S.H. Pang, P. Lewis, and S. Abolhassani. Real-World Duty Cycles and Utilization for Construction Equipment in North Carolina. FHWA/NC/ 2006 - 55, Prepared by North Carolina State University for North Carolina Department of Transportation, Raleigh, NC, 2008. 
15. Frey, H.C., K. Kim, W. Rasdorf, S.H. Pang, and P. Lewis. Comparison of Real World Emissions of Backhoes, Front-End Loaders, and Motor Graders for B20 Biodiesel vs. Petroleum Diesel for Selected Engine Tiers. In Transportation Research Record: Journal of the Transportation Research Board, Transportation Research Board of the National Academies, Washington, D.C., 2008 (In Press).

16. Frey, H.C., K. Kim, S.H. Pang, W. Rasdorf, and P. Lewis. Characterization of Real-World Activity, Fuel Use, and Emissions for Selected Motor Graders Fueled with Petroleum Diesel and B20 Biodiesel. Journal of the Air \& Waste Management Association, In Press.

17. Rasdorf, W., H.C. Frey, P. Lewis, K. Kim, S.H. Pang, and S. Abolhassani. Field Procedures for Measuring Air Pollutant Emissions of Nonroad Diesel Engine Construction Vehicles. Journal of Construction Engineering and Management, American Society of Civil Engineers, Submitted October 2007.

18. Battelle. Environmental Technology Verification Report: Clean Air Technologies International, Inc. REMOTE On-Board Emissions Monitor, Prepared by Battelle for the U.S. Environmental Protection Agency, Columbus, OH, 2003.

19. Stephens, R.D. and S.H. Cadle. Remote Sensing Measurements of Carbon Monoxide Emissions from On-Road Vehicles, J. Air \& Waste Management Association, 41:39-46, 1991.

20. ASTM Standard D6751, "Specification for Biodiesel Fuel Blend Stock (B100) for Middle Distillate Fuels," ASTM International, West Conshohocken, PA, 2008. 


\section{List of Figures and Tables}

TABLE 1 Measured Average Emission Rates of B20 Biodiesel versus Petroleum Diesel for NCDOT Backhoes, Front-End Loaders, and Motor Graders

TABLE 2 Estimated Average Annual Fuel Use for Backhoes, Front-End Loaders, and Motor Graders in the Case Study Fleet

TABLE 3 Estimated Average Annual Emissions for Backhoes, Front-End Loaders, and Motor Graders in the Case Study Fleet

TABLE 4 Estimated Average Annual Emissions Comparisons Based on Fuel Type for Backhoes, Front-End Loaders, and Motor Graders in the Case Study Fleet ${ }^{1}$

TABLE 5 Estimated Average Annual Emissions Comparisons Based on Engine Tier Classifications for Backhoes, Front-End Loaders, and Motor Graders in the Case Study Fleet $^{1}$

TABLE 6 Estimated Average Annual Emissions Based on Using B20 Only in the Highest Available Engine Tier for Backhoes, Front-End Loaders, and Motor Graders in the Case Study Fleet 
TABLE 1 Measured Average Emission Rates of B20 Biodiesel versus Petroleum Diesel for NCDOT Backhoes, Front-End Loaders, and Motor Graders

\begin{tabular}{|c|c|c|c|c|c|c|c|c|c|c|c|c|c|}
\hline & \multicolumn{3}{|c|}{$\begin{array}{c}\mathrm{NO}^{1} \\
\text { (g/gallon) }\end{array}$} & \multicolumn{3}{|c|}{$\begin{array}{c}\text { Opacity-based } \mathbf{P M}^{2} \\
\text { (g/gallon) }\end{array}$} & \multicolumn{3}{|c|}{$\begin{array}{c}\text { CO } \\
\text { (g/gallon) }\end{array}$} & \multicolumn{3}{|c|}{$\begin{array}{c}\text { HC } \\
\text { (g/gallon) }\end{array}$} \\
\hline & & $\mathbf{B 2 0}^{3}$ & $\mathbf{P D}^{4}$ & $\% \Delta^{5}$ & $\mathbf{B 2 0}^{3}$ & $\mathbf{P D}^{4}$ & $\% \Delta^{5}$ & B20 $^{3}$ & PD $^{4}$ & $\% \Delta^{5}$ & B20 $^{3}$ & $\mathbf{P D}^{4}$ & $\% \Delta^{5}$ \\
\hline \multirow{4}{*}{ Backhoes } & Tier 0 & 108 & 105 & +2.9 & 1.16 & 1.20 & \begin{tabular}{|l|}
-3.3 \\
\end{tabular} & 72 & 88 & -18 & 13.9 & 15.4 & $\begin{array}{l}-9.7 \\
\end{array}$ \\
\hline & $\begin{array}{l}\text { Tier } 1 \\
\end{array}$ & 94 & 104 & -9.6 & 1.06 & 1.31 & -19 & 38 & 44 & -14 & 8.5 & 10.1 & -16 \\
\hline & Tier 2 & 97 & 99 & -2.0 & 0.54 & 0.71 & -24 & 10 & 13 & -23 & 5.8 & 10.4 & -44 \\
\hline & Avg. & 100 & 103 & -2.9 & 0.92 & 1.07 & -14 & 40 & 48 & -17 & 9.4 & 12.0 & -22 \\
\hline \multirow{3}{*}{$\begin{array}{c}\text { Front- } \\
\text { End } \\
\text { Loaders }\end{array}$} & Tier 1 & 121 & 122 & -0.8 & 0.61 & 0.81 & -25 & 10.9 & 14.9 & -27 & 8.6 & 15.7 & -45 \\
\hline & Tier 2 & 93 & 95 & -2.1 & 0.57 & 0.63 & -9.5 & 9.0 & 11.0 & -18 & 5.0 & 5.6 & -10 \\
\hline & Avg. & 112 & 113 & -0.9 & 0.60 & 0.75 & -20 & 10.3 & 13.6 & -24 & 7.4 & 12.3 & -40 \\
\hline \multirow{5}{*}{$\begin{array}{c}\text { Motor } \\
\text { Graders }\end{array}$} & Tier 0 & 131 & 134 & -2.2 & 0.81 & 0.96 & -16 & 25.6 & 33.1 & -23 & 14.6 & 16.6 & -12 \\
\hline & Tier 1 & 108 & 109 & -0.9 & 0.68 & 0.84 & -19 & 13.6 & 14.6 & -6.8 & 12.8 & 16.4 & -22 \\
\hline & Tier 2 & 102 & 98 & +4.1 & 0.50 & 0.63 & -21 & 10.8 & 11.9 & -9.2 & 8.7 & 11.8 & -26 \\
\hline & Tier 3 & 69 & 68 & +1.5 & 0.47 & 0.57 & -18 & 5.4 & 9.0 & -40 & 5.0 & 6.2 & -19 \\
\hline & Avg. & 102 & 102 & 0.0 & 0.62 & 0.75 & -17 & 13.9 & 17.2 & -19 & 10.3 & 12.8 & -20 \\
\hline
\end{tabular}

${ }^{1} \mathrm{NO}$ is reported as equivalent $\mathrm{NO}_{2}$.

${ }^{2}$ These numbers are useful for comparisons but not as accurate absolute values.

${ }^{3} \mathrm{~B} 20=\mathrm{B} 20$ Biodiesel

${ }^{4} \mathrm{PD}=$ Petroleum Diesel

${ }^{5}$ The percentage change when using B20 biodiesel compared to petroleum diesel, on an equivalent energy basis.

${ }^{6}$ There were no Tier 0 front-end loaders tested during this study, thus Tier 1 emission rates were used for Tier 0 front-end loaders.

Source: These data are summarized based on Frey et al $(14,15)$. 
TABLE 2 Estimated Average Annual Fuel Use for Backhoes, Front-End Loaders, and Motor Graders in the Case Study Fleet

\begin{tabular}{|c|c|c|c|c|c|}
\hline & \multirow{3}{*}{$\begin{array}{c}\begin{array}{c}\text { Vehicles } \\
\text { (each) }\end{array} \\
119\end{array}$} & \multirow{3}{*}{$\begin{array}{c}\begin{array}{c}\text { B20 Biodiesel } \\
\text { (gallons) }\end{array} \\
16,100\end{array}$} & \multirow{3}{*}{$\begin{array}{c}\begin{array}{c}\text { Petroleum Diesel } \\
\text { (gallons) }\end{array} \\
63,300\end{array}$} & \multirow{3}{*}{$\begin{array}{c}\text { TOTAL } \\
79,400\end{array}$} \\
\hline & & & & & \\
\hline \multirow{4}{*}{ Backhoes } & Tier 0 & & & & \\
\hline & Tier 1 & 116 & 17,800 & 75,400 & 93,200 \\
\hline & Tier 2 & 52 & 3,600 & 22,700 & 26,300 \\
\hline & Total & 287 & 37,500 & 161,400 & 198,900 \\
\hline \multirow{4}{*}{$\begin{array}{l}\text { Front-End } \\
\text { Loaders }\end{array}$} & Tier 0 & 107 & 8,300 & 41,300 & 49,600 \\
\hline & Tier 1 & 76 & 9,900 & 57,000 & 66,900 \\
\hline & Tier 2 & 55 & 6,400 & 55,800 & 62,200 \\
\hline & Total & 238 & 24,600 & 154,100 & 178,700 \\
\hline \multirow{5}{*}{ Motor Graders } & Tier 0 & 185 & 26,600 & 132,700 & 159,300 \\
\hline & Tier 1 & 255 & 85,800 & 388,000 & 473,800 \\
\hline & Tier 2 & 60 & 6,500 & 138,900 & 145,400 \\
\hline & Total & 500 & 118,900 & 659,600 & 778,500 \\
\hline & TOTAL & 1,025 & 181,000 & 975,100 & $1,156,100$ \\
\hline
\end{tabular}


TABLE 3 Estimated Average Annual Emissions for Backhoes, Front-End Loaders, and Motor Graders in the Case Study Fleet

\begin{tabular}{|c|c|c|c|c|c|c|c|c|c|c|c|c|c|}
\hline & \multicolumn{3}{|c|}{$\begin{array}{c}\mathrm{NO}^{1} \\
\text { (tons/year) }\end{array}$} & \multicolumn{3}{|c|}{$\begin{array}{c}\text { Opacity-based PM } \\
\text { (tons/year) }\end{array}$} & \multicolumn{3}{|c|}{$\begin{array}{c}\mathrm{CO} \\
\text { (tons/year) }\end{array}$} & \multicolumn{3}{|c|}{$\begin{array}{c}\mathrm{HC} \\
\text { (tons/year) }\end{array}$} \\
\hline & & $\mathrm{B20}^{3}$ & $\mathbf{P D}^{4}$ & Total & $\mathrm{B20}^{3}$ & $\mathbf{P D}^{4}$ & Total & $\mathrm{B20}^{3}$ & $\mathbf{P D}^{4}$ & Total & B20 $^{3}$ & $\mathbf{P D}^{4}$ & Total \\
\hline \multirow{4}{*}{ Backhoes } & Tier 0 & 1.9 & 7.3 & 9.2 & 0.021 & 0.084 & 0.104 & $\begin{array}{ll}1.3 \\
\end{array}$ & 6.1 & $\begin{array}{l}7.4 \\
\end{array}$ & 0.2 & 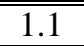 & 1.3 \\
\hline & Tier 1 & 1.8 & 8.6 & 10.5 & 0.021 & 0.109 & 0.130 & 0.7 & 3.7 & 4.4 & 0.2 & 0.8 & 1.0 \\
\hline & Tier 2 & 0.4 & 2.5 & 2.9 & 0.002 & 0.018 & 0.020 & 0.04 & 0.3 & 0.4 & 0.02 & 0.3 & 0.3 \\
\hline & Total & 4.1 & 18.4 & 22.6 & 0.043 & 0.210 & 0.254 & 2.1 & 10.1 & 12.2 & 0.4 & 2.2 & 2.6 \\
\hline \multirow{4}{*}{$\begin{array}{l}\text { Front- } \\
\text { End } \\
\text { Loaders }\end{array}$} & Tier $0^{5}$ & 1.1 & 5.6 & 6.7 & 0.006 & 0.037 & 0.042 & 0.1 & 0.7 & 0.8 & 0.1 & 0.7 & 0.8 \\
\hline & Tier 1 & 1.3 & 7.7 & 9.0 & 0.007 & 0.051 & 0.058 & 0.1 & 0.9 & 1.1 & 0.1 & 1.0 & 1.1 \\
\hline & Tier 2 & 0.7 & 5.8 & 6.5 & 0.004 & 0.039 & 0.043 & 0.1 & 0.7 & 0.7 & 0.04 & 0.3 & 0.4 \\
\hline & Total & 3.1 & 19.1 & 22.1 & 0.016 & 0.127 & 0.143 & 0.3 & 2.3 & 2.6 & 0.2 & 2.0 & 2.3 \\
\hline \multirow{5}{*}{$\begin{array}{l}\text { Motor } \\
\text { Graders }\end{array}$} & Tier 0 & 3.8 & 19.6 & 23.4 & 0.024 & 0.140 & 0.164 & 0.7 & 4.8 & 5.6 & 0.4 & 2.4 & 2.9 \\
\hline & Tier 1 & 10.2 & 46.6 & 56.8 & 0.064 & 0.359 & 0.423 & 1.3 & 6.2 & 7.5 & 1.2 & 7.0 & 8.2 \\
\hline & Tier 2 & 0.7 & 15.0 & 15.7 & 0.004 & 0.096 & 0.100 & 0.1 & 1.8 & 1.9 & 0.1 & 1.8 & 1.9 \\
\hline & Total & 14.8 & 81.1 & 95.9 & 0.092 & 0.596 & 0.687 & 2.1 & 12.9 & 15.0 & 1.7 & 11.2 & 12.9 \\
\hline & TOTAL & 22 & 119 & 141 & 0.15 & 0.93 & 1.1 & 4.5 & 25 & 30 & 2.3 & 15 & 18 \\
\hline
\end{tabular}

${ }^{1} \mathrm{NO}$ is reported as equivalent $\mathrm{NO}_{2}$.

${ }^{2}$ These numbers are useful for comparisons but not as accurate absolute values.

${ }^{3} \mathrm{~B} 20=$ B20 Biodiesel

${ }^{4} \mathrm{PD}=$ Petroleum Diesel

${ }^{5}$ There were no Tier 0 front-end loaders tested during this study, thus Tier 1 emission factors were used for Tier 0 front-end loaders. 
TABLE 4 Estimated Average Annual Emissions Comparisons Based on Fuel Type for Backhoes, Front-End Loaders, and Motor Graders in the Case Study Fleet ${ }^{1}$

\begin{tabular}{|c|c|c|c|c|c|c|c|c|c|c|}
\hline \multirow[b]{2}{*}{ Vehicle } & \multirow[b]{2}{*}{ Pollutant } & \multirow[b]{2}{*}{$\begin{array}{c}\text { Current } \\
\text { Fuel Mix } \\
\text { (tons/yr) }\end{array}$} & \multicolumn{3}{|c|}{ Petroleum Only } & \multicolumn{3}{|c|}{ B20 Only } & \multicolumn{2}{|c|}{$\begin{array}{c}\text { B20 Only vs. } \\
\text { Petroleum Only }\end{array}$} \\
\hline & & & $\begin{array}{c}\text { Total } \\
\text { (tons/yr) }\end{array}$ & $\begin{array}{c}\text { Current } \\
\text { Mix vs. } \\
\text { Petroleum } \\
\text { Only } \\
\text { (tons/yr) } \\
\end{array}$ & $\% \Delta$ & $\begin{array}{c}\text { Total } \\
\text { (tons/yr) }\end{array}$ & $\begin{array}{c}\text { B20 Only } \\
\text { vs. } \\
\text { Current } \\
\text { Mix } \\
\text { (tons/yr) } \\
\end{array}$ & $\% \Delta$ & $\begin{array}{l}\text { Change } \\
\text { (tons/yr) }\end{array}$ & $\% \Delta$ \\
\hline \multirow{4}{*}{ Backhoes } & $\mathrm{NO}^{2}$ & 22.6 & 22.8 & -0.2 & -0.9 & 21.5 & -1.1 & -4.7 & -1.3 & -5.7 \\
\hline & $\mathbf{P M}^{3}$ & 0.25 & 0.26 & -0.01 & -3.9 & 0.22 & -0.03 & -11.1 & -0.04 & -15.4 \\
\hline & $\mathrm{HC}$ & 2.6 & 2.7 & -0.1 & -3.7 & 2.2 & -0.4 & -15.0 & -0.4 & -18.5 \\
\hline & $\mathrm{CO}$ & 12.2 & 12.6 & -0.4 & -3.2 & 10.3 & -1.9 & -15.4 & -2.3 & -18.3 \\
\hline \multirow{4}{*}{$\begin{array}{l}\text { Front- } \\
\text { End } \\
\text { Loaders }\end{array}$} & $\mathrm{NO}^{2}$ & 22.1 & 22.2 & -0.1 & -0.5 & 21.5 & -0.6 & -2.7 & -0.7 & -3.2 \\
\hline & $\mathbf{P M}^{3}$ & 0.14 & 0.15 & -0.01 & -6.7 & 0.12 & -0.02 & -19.2 & -0.03 & -20.0 \\
\hline & $\mathrm{HC}$ & 2.3 & 2.4 & -0.1 & -4.2 & 1.4 & -0.9 & -36.9 & -1.0 & -41.7 \\
\hline & $\mathrm{CO}$ & 2.6 & 2.7 & -0.1 & -3.7 & 2.0 & -0.6 & -23.0 & -0.7 & -25.9 \\
\hline \multirow{4}{*}{$\begin{array}{l}\text { Motor } \\
\text { Graders }\end{array}$} & $\mathrm{NO}^{2}$ & 95.9 & 96.4 & -0.5 & -0.5 & 94.1 & -1.8 & -2.0 & -2.3 & -2.4 \\
\hline & $\mathbf{P M}^{3}$ & 0.69 & 0.71 & -0.02 & -2.8 & 0.57 & -0.12 & -17.4 & -0.14 & -19.7 \\
\hline & $\mathrm{HC}$ & 12.9 & 13.4 & -0.5 & -3.7 & 10.5 & -2.4 & -19.2 & -2.9 & -21.6 \\
\hline & $\mathrm{CO}$ & 15.0 & 15.4 & -0.4 & -2.6 & 13.1 & -1.9 & -12.8 & -2.3 & -14.9 \\
\hline \multirow{4}{*}{$\begin{array}{c}\text { Fleet } \\
\text { Totals }\end{array}$} & $\mathrm{NO}^{2}$ & 140.6 & 141.4 & -0.8 & -0.6 & 137.1 & -3.5 & -2.5 & -4.3 & -3.0 \\
\hline & $\mathbf{P M}^{3}$ & 1.08 & 1.12 & -0.04 & -3.6 & 0.91 & -0.17 & -15.7 & -0.21 & -18.8 \\
\hline & $\mathbf{H C}$ & 17.8 & 18.5 & -0.7 & -3.8 & 14.1 & -3.7 & -20.8 & -4.3 & -23.7 \\
\hline & $\mathrm{CO}$ & 29.8 & 30.7 & -0.9 & -2.9 & 25.4 & -4.4 & -14.8 & -5.3 & -17.3 \\
\hline
\end{tabular}

${ }^{1}$ This estimate is based on the current distribution of engine tiers in the case study fleet.

${ }^{2} \mathrm{NO}$ reported as equivalent $\mathrm{NO}_{2}$

${ }^{3}$ Opacity-based PM; these numbers are useful for comparisons but not as accurate absolute values.

${ }^{4}$ Petroleum diesel is the base case for the comparison between B20 only and Petroleum only. 
TABLE 5 Estimated Average Annual Emissions Comparisons Based on Engine Tier Classifications for Backhoes, Front-End Loaders, and Motor Graders in the Case Study Fleet $^{1}$

\begin{tabular}{|c|c|c|c|c|c|c|c|c|}
\hline \multirow{2}{*}{ Vehicle } & \multirow{2}{*}{ Pollutant } & \multirow{2}{*}{$\begin{array}{c}\text { Current } \\
\text { Engine } \\
\text { Tiers } \\
\text { (tons/yr) }\end{array}$} & \multicolumn{3}{|c|}{$\begin{array}{c}\text { Replace Tier } 0 \text { \& Tier } 1 \text { with } \\
\text { Tier } 2\end{array}$} & \multicolumn{3}{|c|}{$\begin{array}{c}\text { Replace Tier 0, Tier } 1, \& \text { Tier } 2 \\
\text { with Tier } 3\end{array}$} \\
\hline & & & $\begin{array}{c}\text { Total } \\
\text { (tons } / \mathbf{y r} \text { ) }\end{array}$ & $\begin{array}{l}\text { Change } \\
\text { (tons/yr) }\end{array}$ & $\% \Delta$ & $\begin{array}{c}\text { Total } \\
\text { (tons/yr) }\end{array}$ & $\begin{array}{l}\text { Change } \\
\text { (tons/yr) }\end{array}$ & $\% \Delta$ \\
\hline \multirow{4}{*}{ Backhoes } & $\begin{array}{l}\mathrm{NO}^{2} \\
\end{array}$ & 22.6 & 21.6 & -1.0 & -4.4 & NA & NA & NA \\
\hline & $\mathbf{P M}^{\mathbf{3}}$ & 0.25 & 0.15 & -0.1 & -40.0 & NA & NA & NA \\
\hline & $\mathrm{HC}$ & 2.6 & 2.1 & -0.5 & -19.2 & NA & NA & NA \\
\hline & $\mathrm{CO}$ & 12.2 & 2.7 & -9.5 & -77.9 & NA & NA & NA \\
\hline \multirow{4}{*}{$\begin{array}{l}\text { Front-End } \\
\text { Loaders }\end{array}$} & $\mathrm{NO}^{2}$ & 22.1 & 18.7 & -3.4 & -15.4 & NA & NA & NA \\
\hline & $\mathbf{P M}^{\mathbf{3}}$ & 0.14 & 0.12 & -0.02 & -14.3 & NA & NA & NA \\
\hline & $\mathrm{HC}$ & 2.3 & 1.1 & -1.2 & -52.2 & NA & NA & NA \\
\hline & $\mathrm{CO}$ & 2.6 & 2.1 & -0.5 & -19.2 & NA & NA & NA \\
\hline \multirow{4}{*}{$\begin{array}{l}\text { Motor } \\
\text { Graders }\end{array}$} & $\mathrm{NO}^{2}$ & 95.9 & 84.5 & -11.4 & -11.9 & 58.4 & -37.5 & -39.1 \\
\hline & $\mathbf{P M}^{3}$ & 0.69 & 0.52 & -0.17 & -24.6 & 0.48 & -0.21 & -30.4 \\
\hline & $\mathrm{HC}$ & 12.9 & 9.7 & -3.2 & -24.8 & 5.2 & -7.7 & -59.7 \\
\hline & $\mathrm{CO}$ & 15.0 & 10.1 & -4.9 & -32.7 & 7.2 & -7.8 & -52.0 \\
\hline \multirow{4}{*}{$\begin{array}{l}\text { Fleet } \\
\text { Totals }\end{array}$} & $\mathrm{NO}^{2}$ & 140.6 & 124.8 & -15.8 & -11.2 & NA & NA & NA \\
\hline & $\mathbf{P M}^{3}$ & 1.08 & 0.79 & -0.29 & -26.9 & NA & NA & NA \\
\hline & $\mathrm{HC}$ & 17.8 & 12.9 & -4.9 & -27.5 & NA & NA & NA \\
\hline & $\mathrm{CO}$ & 29.8 & 14.9 & -14.9 & -50.0 & NA & NA & NA \\
\hline
\end{tabular}

${ }^{1}$ This estimate is based on the current fuel mix distribution of the vehicles in the case study fleet.

${ }^{2} \mathrm{NO}$ reported as equivalent $\mathrm{NO}_{2}$

${ }^{3}$ Opacity-based PM, these numbers are useful for comparisons but not as accurate absolute values. 
TABLE 6 Estimated Average Annual Emissions Based on Using B20 Only in the Highest Available Engine Tier for Backhoes, Front-End Loaders, and Motor Graders in the Case Study Fleet

\begin{tabular}{|c|c|c|c|c|c|}
\hline \multirow[b]{2}{*}{ Vehicle } & \multirow[b]{2}{*}{ Pollutant } & \multirow{2}{*}{$\begin{array}{c}\text { Current } \\
\text { Fuel Mix } \\
\text { \& Tiers } \\
\text { (tons/yr) }\end{array}$} & \multicolumn{3}{|c|}{ B20 Only \& Highest Tier ${ }^{1}$} \\
\hline & & & $\begin{array}{c}\text { Total } \\
\text { (tons/yr) }\end{array}$ & $\begin{array}{c}\text { Change } \\
\text { (tons/yr) }\end{array}$ & $\% \Delta$ \\
\hline \multirow{4}{*}{ Backhoes } & $\mathrm{NO}^{2}$ & 22.6 & 20.9 & -1.7 & -7.5 \\
\hline & $\mathbf{P M}^{3}$ & 0.25 & 0.12 & -0.13 & -52.0 \\
\hline & $\mathrm{HC}$ & 2.6 & 1.2 & -1.4 & -53.8 \\
\hline & $\mathrm{CO}$ & 12.2 & 2.2 & -10.0 & -82.0 \\
\hline \multirow{4}{*}{$\begin{array}{l}\text { Front-End } \\
\text { Loaders }\end{array}$} & $\mathrm{NO}^{2}$ & 22.1 & 18.0 & -4.1 & -18.6 \\
\hline & $\mathbf{P M}^{3}$ & 0.14 & 0.11 & -0.03 & -21.4 \\
\hline & $\mathrm{HC}$ & 2.3 & 1.0 & -1.3 & -56.5 \\
\hline & $\mathrm{CO}$ & 2.6 & 1.7 & -0.9 & -34.6 \\
\hline \multirow{4}{*}{ Motor Graders } & $\mathrm{NO}^{2}$ & 95.9 & 58.2 & -37.7 & -39.3 \\
\hline & $\mathbf{P M}^{3}$ & 0.69 & 0.40 & -0.29 & -42.0 \\
\hline & $\mathrm{HC}$ & 12.9 & 4.2 & -8.7 & -67.4 \\
\hline & $\mathrm{CO}$ & 15.0 & 4.6 & -10.4 & -69.3 \\
\hline \multirow{4}{*}{ Fleet Totals } & $\mathrm{NO}^{2}$ & 140.6 & 97.1 & -43.5 & -30.9 \\
\hline & $\mathbf{P M}^{3}$ & 1.08 & 0.63 & -0.45 & -41.7 \\
\hline & $\mathbf{H C}$ & 17.8 & 6.4 & -11.4 & -64.0 \\
\hline & $\mathrm{CO}$ & 29.8 & 8.5 & -21.3 & -71.5 \\
\hline
\end{tabular}

${ }^{1}$ The highest tier available is Tier 2 for backhoes and front-end loaders and Tier 3 for motor graders.

${ }^{2} \mathrm{NO}$ reported as equivalent $\mathrm{NO}_{2}$.

${ }^{3}$ Opacity-based PM, these numbers are useful for comparisons but not as accurate absolute values. 